\title{
Pelatihan Aplikasi XRecorder untuk Media Pembelajaran Daring bagi Guru SD
}

\author{
Training of the XRecorder Application for Online Learning Media for Elementary School \\ Teachers
}

Ratri Rahayu*
Himmatul Ulya
Department of Mathematics
Education, Universitas Muria
Kudus, Kudus, Central Java,
Indonesia
email: ratri.rahayu@umk.ac.id
Kata Kunci
Aplikasi Android
Daring
Media pembelajaran
XRecorder
Keywords:
Android application
Online learning
Learning Media
XRecorder

\begin{abstract}
Abstrak
Merebaknya virus Covid-19 berdampak pada berubahnya kegiatan belajar yang awalnya tatap muka menjadi daring. Peralihan ini memunculkan banyak kendala bagi guru terutama penggunaan teknologi. Guru SDN 2 Margoyoso kesulitan untuk membuat video penjelasan materi pelajaran. Guru hanya mengirimkan pesan teks berupa instruksi untuk mengerjakan tugas, tanpa mengirimkan video pembelajaran. Hal ini membuat siswa jenuh dan tidak bisa memahami isi pelajaran dengan baik. Tujuan dari kegiatan pengabdian ini adalah memberikan pengetahuan kepada guruguru SDN 2 Margoyoso mengenai pemanfaatan aplikasi XRecorder untuk media pembelajaran daring. Kegiatan pengabdian ini dilaksanakan di SDN 2 Margoyoso dengan peserta 1 kepala sekolah dan 13 orang guru. Kegiatan dilaksanakan pada tanggal 15 dan 18 Februari 2021. Metode yang digunakan dalam pengabdian ini adalah dengan memberikan pelatihan interaktif dan pelatihan. Selanjutnya, dalam proses pelatihan ada interaksi dua arah sehingga memberikan kesempatan kepada guru-guru di SDN 2 Margoyoso sebagai peserta pelatihan untuk menyumbangkan ide, pendapat, pikiran, dan pengalamannya. Pelaksanaan pelatihan dilaksanakan dalam beberapa tahap, antara lain: perencanaan, pelaksanaan, follow up, dan evaluasi. Kegiatan pengabdian pelatihan mampu meningkatkan keterampilan guru dalam inovasi pembelajaran daring, hal ini terwujud dari guru di SDN 2 Margoyoso mampu melakukan simulasi dan praktik pemanfaatan aplikasi XRecorder dalam video pembelajaran daring.
\end{abstract}

\begin{abstract}
The outbreak of the Covid-19 virus impacted changing learning activities from faceto-face to online. This transition raises many obstacles for teachers, especially the use of technology. SDN 2 Margoyoso teachers have difficulty making video explanations of subject matter. The teacher only sends text messages in the form of instructions for doing assignments without sending learning videos. This makes students bored and unable to understand the lesson's content well. This service activity aims to provide knowledge to SDN 2 Margoyoso teachers about the use of the XRecorder application for online learning media. This service activity was conducted at SDN 2 Margoyoso with one school principal and 13 teachers as participants. The action was held on February 15 and 18, 2021. The method used in this service was to provide interactive training and training. Furthermore, there is a two-way interaction in the training process to provide opportunities for teachers at SDN 2 Margoyoso as training participants to contribute their ideas, opinions, thoughts, and experiences. The training is carried out in several stages, including planning, implementation, follow-up, and evaluation. Training service activities were able to improve teacher skills in online learning innovation. This was manifested by teachers at SDN 2 Margoyoso being able to simulate and practice using the XRecorder application in online learning videos.
\end{abstract} (http://creativecommons.org/licenses/by-sa/4.0/). DOI: https://doi.org/10.33084/pengabdianmu.v7i1.2290 


\section{PENDAHULUAN}

Mulai awal tahun 2020, dunia mulai diresahkan dengan munculnya Coronavirus Disease (Covid-19) di Wuhan China. Virus ini menyebar ke seluruh dunia, termasuk Indonesia. Terhitung Maret tahun 2020, WHO menetapkan Covid-19 sebagai pandemi (Sohrabi et al., 2020). Bahaya virus ini dapat mengganggu kesehatan hingga berujung pada kematian. Pandemi Covid-19 berdampak pada semua aspek kehidupan manusia. Pemerintah Indonesia sudah melakukan beberapa upaya guna mencegah penyebaran Covid-19, mulai dari kampanye protokol kesehatan, pembatasan social berskala besar (PSBB), pelarangan mudik, anjuran untuk bekerja, belajar, dan beribadah dari rumah.

Aspek pendidikan juga terdampak atas kebijakan pemerintah agar masyarakat bisa bekerja dan belajar dari rumah. Pembelajaran tatap muka di sekolah diubah menjadi kegiatan belajar mengajar (KBM) daring karena situasi dan kondisi yang belum stabil serta masih meningkatnya kasus positif Covid-19. Beragam cara pelaksanaan pembelajaran daring, diantaranya video converence online, pembuatan video pembelajaran, pemanfaatan konten-konten pendidikan gratis, dan pemanfaatan portal kegiatan belajar yang disediakan Kemendikbud melalui siaran televisi (Dewi, 2020). Selama pandemi, siswa melakukan pembelajaran tidak langsung dengan memanfaatkan pembelajaran dalam jaringan atau daring (Sadikin \& Hamidah, 2020).

Pembelajaran daring merupakan pembelajaran yang menggunakan jaringan internet dengan aksesibilitas, konektivitas, fleksibilitas, dan kemampuan untuk memunculkan berbagai jenis interaksi pembelajaran. Penggunaan internet dan teknologi multimedia mampu merombak cara penyampaian pengetahuan dan dapat menjadi alternatif pembelajaran yang dilaksanakan dalam kelas tradisional. Pembelajaran daring adalah pembelajaran yang mampu mempertemukan mahasiswa dan dosen untuk melaksanakan interaksi pembelajaran dengan bantuan internet (Kuntarto, 2017).

Peralihan pembelajaran tatap muka menjadi daring memunculkan banyak kendala bagi guru, mengingat pandemi ini terjadi secara mendadak. Guru sekolah dasar yang terbiasa melakukan pembelajaran tatap muka merasa tidak siap dengan kondisi ini. Kelemahan utama pembelajaran daring, yaitu minimnya intensitas pertemuan antar siswa dan pengajar (Wardani et al., 2018). Dalam pembelajaran daring, guru dipaksa melek teknologi yang merupakan satu-satunya jembatan yang bisa menghubungkan guru dan siswa tanpa harus tatap muka (Handarini \& Wulandari, 2020). Kendala yang dialami guru ketika melaksanakan pembelajaran daring antara lain aplikasi pembelajaran, jaringan internet dan gawai, pelaksanaan pembelajaran, asesmen, dan pengawasan (Rigianti, 2020). Meskipun pembelajaran sudah diusahakan melalui daring, akan tetapi tidak semua siswa juga menunjukkan keberhasilan (Nakayama et al., 2007). Pelaksanaan pembelajaran yang didominasi pemberian tugas saja, membuat siswa kurang berminat dalam mengikuti pelajaran. Siswa merasa jenuh akan pembelajaran daring yang monoton karena kurangnya variasi pelaksanaan pembelajaran.

Berdasarkan wawancara yang dilakukan dengan kepala sekolah dan beberapa guru SDN2 Margoyoso Jepara, didapatkan informasi bahwa selama ini guru telah berusaha melakukan pembelajaran daring. Namun, guru mengalami kesulitan untuk menggunakan fasilitas Learning Management System (LMS). Guru biasanya menggunakan aplikasi WhatsApp Group (WAG) untuk mengajar secara daring. Namun, fungsi WAG yang hanya untuk fasilitas pesan kurang mendukung untuk pembelajaran. Guru hanya mengirimkan pesan teks berupa instruksi untuk mengerjakan tugas, tanpa mengirimkan video pembelajaran. Hal ini menyebabkan siswa tidak dapat memahami isi materi pelajaran karena kurang penjelasan dari guru. Permasalahan yang dihadapi oleh guru yaitu kurangnya pengetahuan dan keterampilan dalam pembuatan video pembelajaran. Guru merasa kesulitan dalam hal penggunaan alat ketika harus merekam sekaligus menjelaskan materi. Selain keterbatasan mengenai jenis alat perekaman dan fungsinya, guru juga tidak mengetahui aplikasi edit video dan proses publikasi video yang telah dibuat. Kesulitan-kesulitan yang dialami guru SDN 2 Margoyoso ini menyebabkan mereka enggan untuk membuat video pembelajaran.

Berdasarkan permasalahan yang dihadapi guru-guru matematika di SDN 2 Margoyoso Jepara, maka mereka membutuhkan pengetahuan dan keterampilan pemanfaatan aplikasi XRecorder dalam pembuatan video pembelajaran. Aplikasi XRecorder merekam gambar visual aplikasi ini mampu merekap tayangan slide yang berfungsi untuk menjelaskan berbagai materi disertai gambar visual. Guru dapat memperlihatkan materi pokok serta merekam wajah 
ketika presentasi. Aplikasi XRecorder dipilih karena aplikasi ini secara gratis dapat diunduh dari Playstore, memiliki fitur yang mudah digunakan untuk menjeda/melanjutkan perekaman, mudah untuk dalam hal penyimpanan dalam gawai, dan hasil video dapat diekspor dalam pengaturan yang disesuaikan dengan kebutuhan. Dengan aplikasi yang mudah digunakan tersebut guru menjadi lebih kreatif dan inovatif dalam menciptakan video pembelajaran yang menarik dan materinya mudah dipahami oleh siswa. Selain itu, guru juga akan memiliki pemahaman dan pengetahuan tentang pembuatan media pembelajaran yang virtual. Hal ini dapat dimanfaatkan guru dalam menjelaskan materi pelajaran kepada siswa.

Berdasarkan masalah yang terkait dengan kurangnya pengetahuan dan keterampilan guru dalam memanfaatkan aplikasi XRecorder dalam pembelajaran matematika, maka tim pengabdian merumuskan masalah yang harus diatasi melalui "Pelatihan Pemanfaatan Aplikasi XRecorder untuk Media Pembelajaran Daring Bagi Guru di SDN 2 Margoyoso". Alasan tim pengabdian berorientasi pemecahan masalah pada pelatihan pemanfaatan aplikasi XRecorder dalam pembelajaran daring yaitu membekali guru agar terampil membuat video pembelajaran sebagai upaya untuk meningkatkan pemahaman siswa. Selain itu, pelatihan ini diharapkan dapat mengembangkan kompetensi guru dan turut memotivasi guru untuk tetap bersemangat selama masa pandemi yang bermuara pada peningkatan kualitas dan hasil belajar siswa.

Kegiatan pengabdian ini sebagai upaya untuk membantu guru dalam mengatasi permasalahan selama pembelajaran daring, yaitu untuk menyediakan media berupa video pembelajaran guna menjelaskan materi kepada siswa. Apabila guru tidak menyediakan video pembelajaran, siswa merasa bosan karena harus membaca materi yang diberikan melalui Microsoft Word (Anugrahana, 2020). Selain itu, jika guru membuat video sendiri akan lebih terasa nyaman ditonton oleh siswa, karena siswa telah mengenal sosok yang memberikan penjelasan materi yang dipelajari, dibandingkan menonton video pembelajaran yang dibuat orang lain (Apriani et al., 2020). Tujuan kegiatan pengabdian pada masyarakat ini adalah memberikan pelatihan dan pendampingan pemanfaatan aplikasi sekaligus simulasi XRecorder untuk pembuatan video pembelajaran bagi guru di SDN 2 Margoyoso.

\section{METODE}

Dalam kegiatan pengabdian ini guru didampingi untuk membuat media pembelajaran berupa video menggunakan aplikasi XRecorder. Hal ini dilakukan karena mempertimbangkan ketersediaan sarana prasarana dan juga kemampuan awal guru di lapangan (Syahroni et al., 2020). Aplikasi XRecorder adalah aplikasi yang dapat diunduh di telepon pintar. Aplikasi ini biasa digunakan untuk menangkap aktivitas layar. Video yang dihasilkan cukup bagus untuk diunggah ke akun youtube (Ahmala et al., 2021). Selain untuk merekam gambar visual, aplikasi ini mampu merekam tayangan slide yang berfungsi untuk menjelaskan berbagai materi disertai gambar visual.

Pendekatan yang digunakan dalam pengabdian adalah participant active learning (peserta berpartisipasi secara aktif dalam kegiatan pelatihan). Sedangkan bentuk pelatihan ini adalah pelatihan interaktif dan pendampingan sehingga terjadi interaksi dua arah antara tim pengabdian dan peserta kegiatan. Hal ini bertujuan untuk memberikan kesempatan kepada peserta (guru SDN 2 Margoyoso Kalinyamatan Jepara) untuk menyumbangkan ide, gagasan, pendapat, pikiran, kreativitas, dan pengalamannya sehingga diperoleh ilmu yang akan bermanfaat untuk pembelajaran matematika. Media pembelajaran berupa video membuat peserta didik lebih termotivasi dalam belajar yang pada akhirnya meningkatnya hasil belajar peserta didik (Khairani et al., 2019). Dalam masa pandemi dimana siswa tidak dapat belajar secara langsung dengan guru, akan terfasilitasi jika terdapat video pembelajaran. Metode yang digunakan dalam pelatihan dan pendampingan adalah sebagai berikut:

1. Ceramah

Metode ceramah digunakan untuk menyampaikan materi pelatihan, antara lain soal aplikasi XRecorder, pemanfaatan aplikasi XRecorder, cara memasang aplikasi XRecorder, dan pembuatan video pembelajaran dengan aplikasi XRecorder. 
2. Tanya jawab

Tanya jawab adalah metode penyampaian materi untuk pelatihan yang dilakukan dengan tujuan memberikan kejelasan suatu informasi/ pengetahuan dan konsep. Peserta pelatihan diberikan kesempatan untuk bertanya kepada tim pengabdian untuk memperoleh kejelasan atas suatu informasi yang belum diketahui, dan juga sebaliknya.

3. Diskusi

Kegiatan diskusi dilakukan dengan cara melibatkan peserta pelatihan untuk membahas dan menyelesaikan tugas dalam kegiatan pendampingan. Metode diskusi bertujuan agar terjadi interaksi antara tim pengabdian dengan peserta atau antar peserta untuk bertukar pikiran terkait ide dan gagasan masing-masing.

4. Simulasi

Simulasi merupakan kegiatan yang dilakukan pada waktu dan tempat terbatas sebagai follow up dari teori yang telah dipaparkan. Simulasi dalam pengabdian ini berupa pemaparan dan diskusi video pembelajaran

5. Praktik

Praktik merupakan kegiatan yang dilakukan peserta pelatihan sesuai dengan arahan fasilitator. Peserta pelatihan praktik membuat video pembelajaran dengan menggunakan aplikasi XRecorder.

Kegiatan pengabdian masyarakat tentang pelatihan pemanfaatan aplikasi XRecorder untuk media pembelajaran daring dilaksanakan dengan tahapan perencanaan, pelaksanaan, follow up, simulasi, dan evaluasi. Hal ini sedikit berbeda dengan kegiatan pengabdian Indrawati dan Hartati (2021) yang memiliki tahapan persiapan, pelaksanaan, dan evaluasi.

1. Perencanaan

Merencanakan kegiatan pelatihan pemanfaatan aplikasi XRecorder untuk media pembelajaran daring, menyiapkan perangkat pelatihan, melakukan perizinan dan persiapan tempat pengabdian, serta menyiapkan aplikasi yang akan digunakan

2. Pelaksanaan

Peserta diberikan teori mengenai aplikasi XRecorder dan memanfaatkan aplikasi XRecorder, serta memasang aplikasi XRecorder dan membuat video pembelajaran

3. Follow up

Peserta mampu praktik uji coba memasang aplikasi XRecorder dan membuat video pembelajaran dengan menggunakan aplikasi XRecorder.

4. Simulasi

Pada tahap simulasi, peserta pengabdian melakukan pemaparan dan diskusi hasil video pembelajaran yang telah dibuat.

5. Evaluasi

Mengevaluasi hasil pendampingan dan pemaparan serta diskusi hasil video pembelajaran.

\section{HASIL DAN PEMBAHASAN}

Kegiatan pelatihan pemanfaatan aplikasi XRecorder untuk media pembelajaran daring bagi guru di SDN 2 Margoyoso dilakukan melalui 5 tahapan, yaitu.

1. Perencanaan

Kegiatan yang dilakukan tim pengabdian pada tahap perencanaan dimulai dari kegiatan studi pendahuluan dan analisis kebutuhan. Tujuan kegiatan ini yaitu guna menemukan permasalahan yang dihadapi guru matematika SDN 2 Margoyoso. Studi pendahuluan yang dilakukan adalah dengan melakukan analisis penggunaan teknologi dalam pembelajaran matematika di sekolah dan analisis keterampilan guru dalam memanfaatkan teknologi untuk membuat video pembelajaran. Hasilnya yaitu dalam pembelajaran matematika guru telah berusaha memanfaatkan teknologi, tetapi guru menemui kesulitan untuk membuat video pembelajaran matematika yang dapat digunakan untuk membantu siswa memahami. 
Kegiatan berikutnya yaitu perencanaan ipteks (materi praktik dan pelatihan) dari berbagai literatur tentang pemanfaatan aplikasi XRecorder dalam pembelajaran matematika. Rancangan materi dalam pengabdian ini yaitu materi mengenai aplikasi XRecorder, memanfaatkan aplikasi XRecorder, cara memasang aplikasi XRecorder, dan pembuatan video pembelajaran dengan aplikasi XRecorder. Persiapan program di lapangan dengan proses perizinan kepada kepala SDN 2 Margoyoso serta persiapan peralatan dan tempat dalam melaksanakan pengabdian masyarakat.

2. Pelaksanaan

Pada tahap pelaksanaan, tim pengabdian memberikan pelatihan dan pendampingan pemanfaatan aplikasi XRecorder untuk media pembelajaran matematika kepada 13 orang guru dan 1 kepala SDN 2 Margoyoso. Kegiatan dilaksanakan pada tanggal 15 dan 18 Februari 2021. Kegiatan diawali dengan koordinasi antara kepala sekolah, guru, dan tim pengabdian serta pemberian modul penggunaan XRecorder untuk pelaksanaan kegiatan pengabdian. Kegiatan berikutnya yaitu sosialisasi mengenai aplikasi XRecorder dan cara instalasi aplikasi XRecorder. Materi ini disampaikan oleh Ratri Rahayu, M.Pd. Guru dikenalkan dengan aplikasi XRecorder, fitur-fitur di dalamnya, serta keunggulan dan kelemahan aplikasi XRecorder dibandingkan dengan aplikasi pembuat video sejenis.

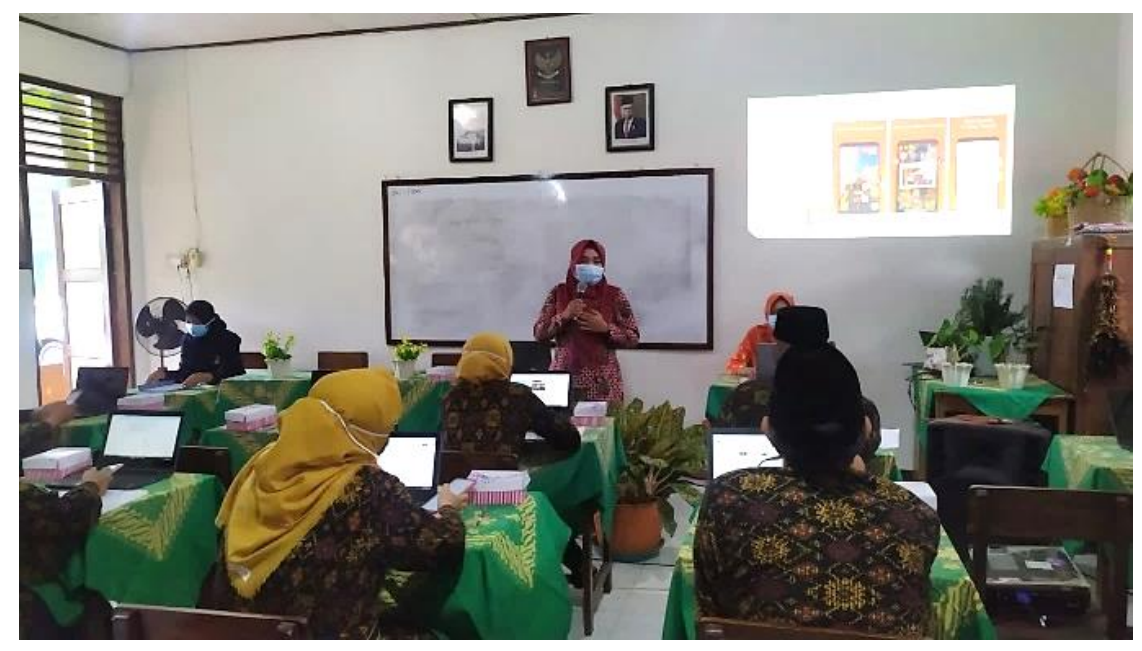

Gambar 1. Sosialisasi mengenai aplikasi XRecorder

Pada tahap sosialisasi kedua, guru matematika di SDN 2 Margoyoso diberikan materi mengenai manfaat XRecorder untuk pembuatan media video pembelajaran matematika. Penyaji materi ini yaitu Himmatul Ulya, M.Pd. Pada kegiatan ini, tim pengabdian juga menjelaskan mengenai langkah-langkah penggunaan aplikasi XRecorder.

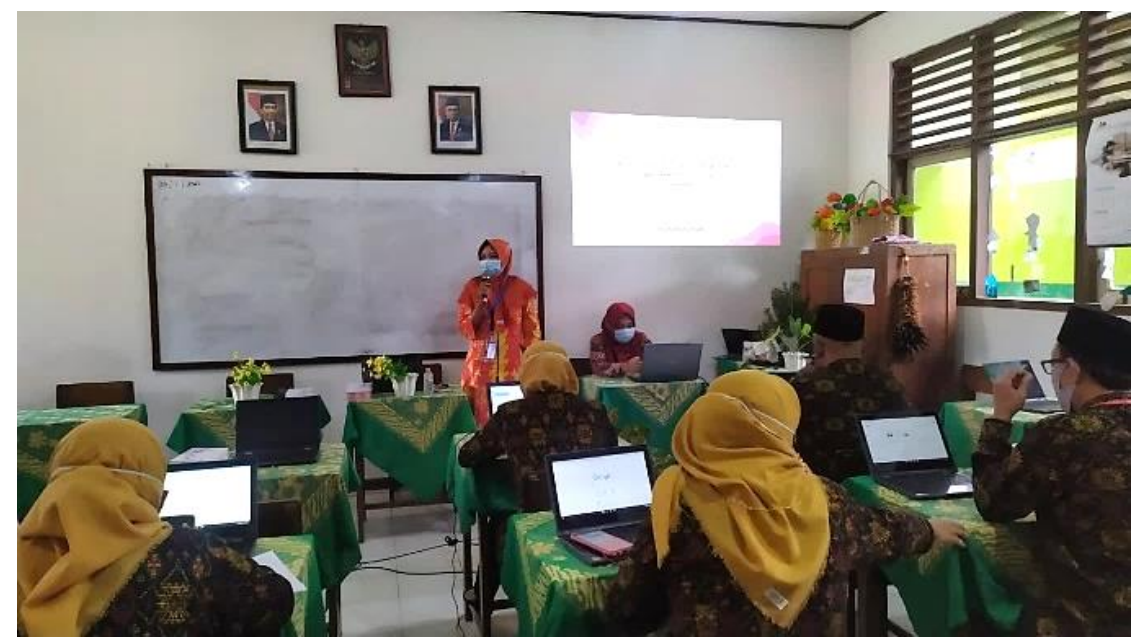

Gambar 2. Sosialisasi langkah penggunaan aplikasi XRecorder 


\section{Follow up}

Pada tahap follow up kegiatan, guru diminta untuk memasang aplikasi XRecorder di gawai masing-masing. Selama proses instalasi aplikasi, tim pengabdian memberikan pendampingan bagi guru yang mengalami hambatan.

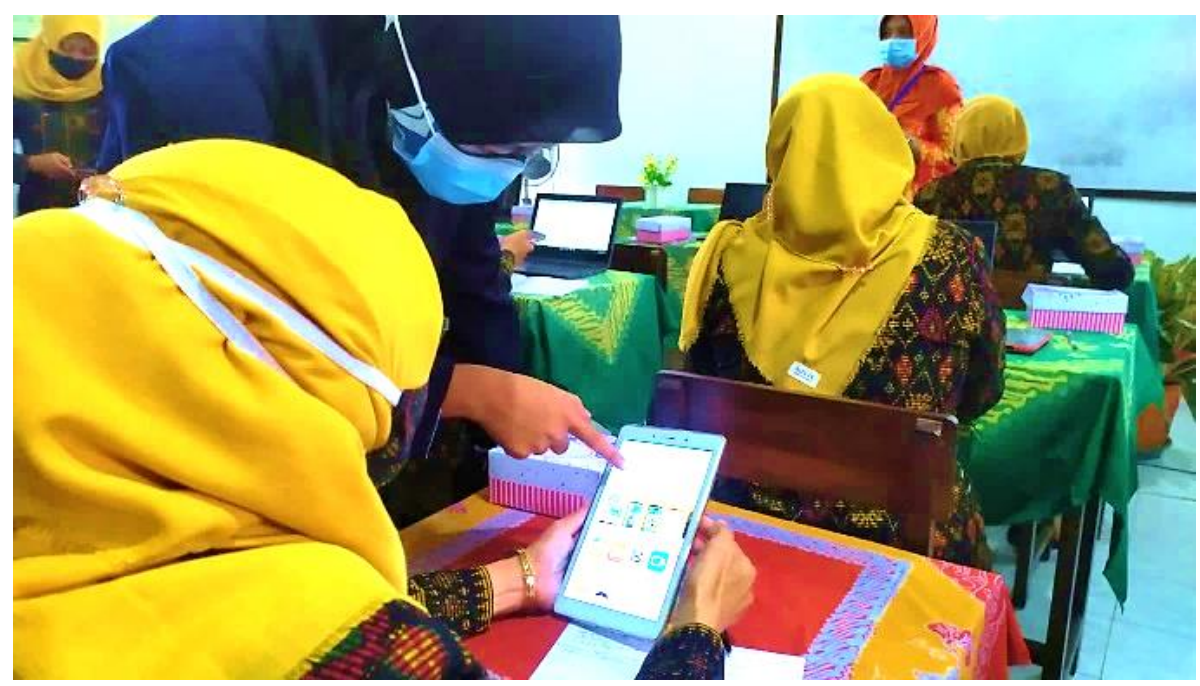

Gambar 2. Pendampingan instalasi aplikasi XRecorder

Setelah berhasil memasang aplikasi XRecorder di gawai, guru diminta untuk praktik uji coba membuat video pembelajaran dengan memanfaatkan aplikasi tersebut. Pada awalnya guru masih mengalami kesulitan karena belum terbiasa dengan fitur-fitur yang ada dalam aplikasi XRecorder. Tim pengabdian memfasilitasi guru dengan melakukan pendampingan mulai dari persiapan file materi, proses perekaman mulai dari pembukaan video, penjelasan materi ini, hingga penutup. Setelah video sudah jadi guru mengecek kembali hasil rekaman video yang telah dibuat. Guru sangat antusias melakukan praktik uji coba terlihat dari antusiasme mereka dalam tanya jawab hingga membuat beberapa video pembelajaran. Para guru SDN 2 Margoyoso menyatakan bahwa aplikasi seperti XRecorder sangat diperlukan oleh guru dalam membantu pembuatan media pembelajaran daring selama pandemi Covid-19.

4. Simulasi

Setelah praktik uji coba membuat video pembelajaran dengan menggunakan aplikasi XRecorder, guru melakukan pemaparan video yang telah dibuat pada tahap simulasi. Peserta pengabdian melakukan pemaparan dilanjut dengan diskusi mengenai video yang telah dibuat.

5. Evaluasi

Pada pengabdian ini dilaksanakan dua tahapan evaluasi, yaitu evaluasi yang dilakukan oleh teman sejawat peserta pendampingan dan evaluasi hasil oleh tim pengabdian.

a. Evaluasi yang dilakukan oleh teman sejawat

Kegiatan evaluasi ini dilakukan oleh teman sejawat berupa kegiatan saling menilai dan memberi saran, masukan, dan penghargaan atas hasil karya produk peserta berupa video pembelajaran.

b. Evaluasi oleh tim pengabdian

Tim pengabdian melakukan kegiatan evaluasi, menilai, memberi saran, masukan dan penghargaan terkait hasil pendampingan, produk pendampingan, dan pemaparan serta diskusi hasil video pembelajaran yang dibuat oleh peserta pengabdian.

Dari hasil evaluasi yang telah dilakukan, diperoleh hasil bahwa kegiatan pengabdian masyarakat tentang pendampingan pemanfaatan aplikasi XRecorder dalam pembelajaran matematika berjalan lancar dan peserta pengabdian merasa antusias, aktif, serta kreatif dalam membuat video pembelajaran. Setelah kegiatan pengabdian, 
guru-guru SDN 2 Margoyoso memperoleh pengetahuan mengenai aplikasi XRecorder dan fitur-fiturnya, pengetahuan mengenai instalasi dan cara menggunakan aplikasi XRecorder, serta gambaran praktik pembuatan video pembelajaran matematika menggunakan aplikasi XRecorder.

\section{KESIMPULAN}

Kegiatan pengabdian pelatihan mampu meningkatkan keterampilan guru dalam inovasi pembelajaran matematika, hal ini terwujud dari guru di SDN 2 Margoyoso mampu melakukan simulasi dan praktik pemanfaatan aplikasi XRecorder dalam video pembelajaran matematika. Guru dapat memanfaatkan berbagai penerapan teknologi sebagai sarana untuk membantu dalam pembelajaran daring.

\section{UCAPAN TERIMA KASIH}

Terima kasih kami sampaikan kepada LPPM Universitas Muria Kudus yang telah memberikan hibah pengabdaian kepada masyarakat. Kami juga mengucapkan banyak terima kasih kepada Ibu Utik Purwanti, S.Pd selaku kepala sekolah serta penghargaan kepada bapak/ibu guru SDN 2 Margoyoso Kalinyamatan Jepara.

\section{REFERENSI}

Ahmala, M., Masitho, D.N., Jannah, T.A.A.R. 2021. XRecorder Application As Arabic Online Learning / Aplikasi XRecorder Sebagai Media Pembelajaran Daring Bahasa Arab. Al Mahära : Jurnal Pendidikan Bahasa Arab. 7(1):64-85. https://doi.org/10.14421/almahara.2021.071-04

Anugrahana, A. 2020. Hambatan, Solusi dan Harapan: Pembelajaran Daring Selama Masa Pandemi Covid-19 Oleh Guru Sekolah Dasar. SCHOLARIA : Jurnal Pendidikan dan Kebudayaan. 10(3):282-289. https://doi.org/https://doi.org/10.24246/j.js.2020.v10.33.p282-289

Apriani, Y., Mafra, R., Oktaviani, W.A. 2020. Pembuatan Video Metode Tangkap Layar Sebagai Media Pembelajaran Daring Di Masa Pandemi Covid-19. JMM (Jurnal Masyarakat Mandiri). 4(6):1049-1057. https://doi.org/https://doi.org/10.31764/jmm.v4i6.2710

Dewi, W.A.F. 2020. Dampak COVID-19 terhadap Implementasi Pembelajaran Daring diSekolah Dasar. Edukatif: Jurnal Ilmu Pendidikan. 2(1):55-61. https://doi.org/10.31004/edukatif.v2i1.89

Handarini, O.I., Wulandari, S.S. 2020. Pembelajaran Daring Sebagai Upaya Study from Home(SFH) Selama Pandemi Covid 19. Jurnal Pendidikan Administrasi Perkantoran (JPAP). 8(3):496-503

Indrawati, F., Hartati, L. 2021. Pelatihan Aplikasi Belajar Berbasis Kuis dalam Upaya Meningkatkan Aktivitas Belajar Siswa. E-Dimas : Jurnal Pengabdian kepada Masyarakat. 12(1):67-73. https://doi.org/10.26877/e-dimas.v12i1.6762

Khairani, M., Sutisna, Suyanto, S. 2019. Studi Meta-Analisis Pengaruh Video Pembelajaran Terhadap Hasil Belajar Peserta Didik. Jurnal Biolokus: Jurnal Penelitian Pendidikan Biologi dan Biologi. 2(1):158-166. http://dx.doi.org/10.30821/biolokus.v2i1.442

Kuntarto, E. 2017. Keefektifan Model Pembelajaran Daring dalam Perkuliahan Bahasa Indonesia di Perguruan Tinggi. Indonesian Language Education and Literature. 3(1):99-110. http://dx.doi.org/10.24235/ileal.v3i1.1820

Nakayama, M., Yamamoto, H., S, R. (2007). The Impact of Learner Characteristics on Learning Performance in Hybrid Courses among Japanese Students. Electronic Journal E-Learning. 5(3):195-206 
Rigianti, H.A. 2020. Kendala Pembelajaran Daring Guru Sekolah Dasar di Kabupaten Banjarnegara. Elementary School : $\begin{array}{lllll}\text { Jurnal Pendidikan dan } & \text { Pembelajaran } & \text { 7(2):297-302. }\end{array}$ https://doi.org/https://doi.org/10.31316/esjurnal.v7i2.777

Sadikin, A., Hamidah, A. 2020. Pembelajaran Daring di Tengah Wabah Covid-19. Biodik: Jurnal Ilmiah Pendidikan Biologi. 6(2):214-224. https://doi.org/10.22437/bio.v6i2.9759

Sohrabi, C., Alsafi, Z., O’Neill, N., Khan, M., Kerwan, A., Al-Jabir, A., et al. 2020. World Health Organization declares global emergency: A review of the 2019 novel coronavirus (COVID-19). Interational Journal of Surgery. 76:71-76. https://doi.org/10.1016/j.ijsu.2020.02.034

Syahroni, M., Dianastiti, F.E., Firmadani, F. 2020. Pelatihan Media Pembelajaran Berbasis Teknologi Informasi untuk Meningkatkan Keterampilan Guru dalam Pembelajaran Jarak Jauh. International Journal of Community Service Learning. 4(3):170-178. https://doi.org/http://dx.doi.org/10.23887/ijcsl.v4i3.28847

Wardani, D.N., Toenlioe, A.J.E., Wedi, A. 2018. Daya Tarik Pembelajaran Di Era 21 Dengan Blended Learning. JKTP: Jurnal Kajian Teknologi Pendidikan. 1(1):13-18 